\title{
Sudden arrhythmia death syndrome in young victims: a five-year retrospective review and two- year prospective molecular autopsy study by next- generation sequencing and clinical evaluation of their first-degree relatives
}

\author{
Chloe M Mak, NS Mok *, HC Shum, WK Siu, YK Chong, Hencher HC Lee, NC Fong, SF Tong, KW Lee, \\ CK Ching, Sammy PL Chen, WL Cheung, CB Tso, WM Poon, CL Lau, YK Lo, PT Tsui, SF Shum, KC Lee
}

\section{A B S T R A C T}

Objective: Sudden arrhythmia death syndrome (SADS) accounts for about $30 \%$ of causes of sudden cardiac death (SCD) in young people. In Hong Kong, there are scarce data on SADS and a lack of experience in molecular autopsy. We aimed to investigate the value of molecular autopsy techniques for detecting SADS in an East Asian population.

Methods: This was a two-part study. First, we conducted a retrospective 5-year review of autopsies performed in public mortuaries on young SCD victims. Second, we conducted a prospective 2-year study combining conventional autopsy investigations, molecular autopsy, and cardiac evaluation of the first-degree relatives of SCD victims. A panel of 35 genes implicated in SADS was analysed by next-generation sequencing.

Results: There were 289 SCD victims included in the 5-year review. Coronary artery disease was the major cause of death (35\%); 40\% were structural heart diseases and $25 \%$ were unexplained. These unexplained cases could include SADS-related conditions. In the 2-year prospective study, 21 SCD victims were examined: $10 \%$ had arrhythmogenic right ventricular cardiomyopathy, 5\% had hypertrophic cardiomyopathy, and $85 \%$ had negative autopsy. Genetic analysis showed $29 \%$ with positive heterozygous genetic variants; six variants were novel. One third of victims had history of syncope, and $14 \%$ had family history of SCD. More than half of the 11 first-degree relatives who underwent genetic testing carried related genetic variants, and $10 \%$ had SADS-related clinical features.

This article was published on 23 Jan 2019 at www.hkmj.org.
Conclusion: This pilot feasibility study shows the value of incorporating cardiac evaluation of surviving relatives and next-generation sequencing molecular autopsy into conventional forensic investigations in diagnosing young SCD victims in East Asian populations. The interpretation of genetic variants in the context of SCD is complicated and we recommend its analysis and reporting by qualified pathologists.

\footnotetext{
Hong Kong Med J 2019;25:21-9

https://doi.org/10.12809/hkmj187256

${ }^{1}$ CM Mak \#, MD, FHKAM (Pathology)

${ }^{2}$ NS Mok * \#, FHKAM (Medicine), FRCP (Edin)

${ }^{3} \mathrm{HC}$ Shum, MRCP (UK)

${ }^{1}$ WK Siu, PhD, FHKAM (Pathology)

${ }^{1}$ YK Chong, FHKCPath, FHKAM (Pathology)

${ }^{1}$ HHC Lee, FRCPath, FHKAM (Pathology)

${ }^{4}$ NC Fong, FHKAM (Paediatrics)

${ }^{1}$ SF Tong, MSc

${ }^{2}$ KW Lee, BNurs

${ }^{1}$ CK Ching, FRCPA, FHKAM (Pathology)

${ }^{1}$ SPL Chen, FRCPA, FHKAM (Pathology)

${ }^{1}$ WL Cheung, MB, BS

${ }^{3}$ CB Tso, FHKCPath

${ }^{3}$ WM Poon, FHKCPath, FHKAM (Pathology)

${ }^{3}$ CL Lau, FHKAM (Medicine)

${ }^{3}$ YK Lo, FHKAM (Medicine)

${ }^{2}$ PT Tsui, FHKAM (Medicine)

${ }^{3}$ SF Shum, FHKCPath, FHKAM (Pathology)

${ }^{1}$ KC Lee, MB, ChB, FHKAM (Pathology)
}

Department of Pathology, Princess Margaret Hospital, Kwai Chung, Hong Kong

Department of Medicine and Geriatrics, Princess Margaret Hospital, Kwai Chung, Hong Kong

Forensic Pathology Service, Department of Health, Hong Kong

Department of Paediatrics, Princess Margaret Hospital, Kwai Chung, Hong Kong

\# The first two authors contributed equally to the work.

* Corresponding author: mokns@ha.org.hk

\footnotetext{
New knowledge added by this study

- This study provides important data on the prevalence and types of sudden arrhythmia death syndrome (SADS) among young victims of sudden cardiac death in an East Asian population.

- This is the first local feasibility study on the service model incorporating cardiac evaluation of surviving relatives and molecular autopsy by next-generation sequencing into the conventional forensic investigations.

Implications for clinical practice or policy

Genomic testing should be conducted on patients with cardiomyopathies and channelopathies.

- Clinical assessment should be provided for at-risk family members irrespective of genetic findings.

- Molecular autopsy together with conventional autopsy conducted by qualified pathologists should be applied to victims of SADS, sudden unexpected death in epilepsy, or sudden infant death syndrome.
} 


\section{年輕猝死個案中的突發心律失常死亡綜合症：} 五年回顧暨兩年以次世代基因測序作基因解剖及 對直系親屬進行臨床評估的前瞻性研究

\author{
麥苗、莫毅成、沈昊翔、蕭慧君、張耀君、李漢芝、方乃聰 \\ 湯瑞芬、李嘉慧、程楚君、陳柏林、張榮蘭、曹志斌、 \\ 潘偉明、劉駿良、盧應強、徐炳添、沈瑞楓、李錦昌
}

目的：突發性心律失常死亡綜合徵 (SADS) 大約佔年輕人心源性猝 死（SCD）原因的30\%。在香港, 有關SADS的資料稀少, 基因解剖 的經驗亦不足。本研究旨在檢視透過對直系親屬進行臨床評估及為猝 死者進行基因解剖技術於東亞人中診斷SADS的價值

方法：這項研究包括兩部分：首先回顧以往五年公眾殮房為年輕SCD 猝死者進行之解剖, 繼而進行為期兩年的前瞻性研究, 包括傳統解 剖、基因解剖和對SCD猝死者直系親屬的心臟系統臨床評估。是次研 究應用次世代基因測序, 分析與SADS相關的35個基因

結果：研究首部份的五年回顧中包括289名SCD猝死者：其中主要 死因為冠狀動脈疾病（35\%)，其次為結構性心臟病（40\%）; 另外 $25 \%$ 原因不明, 當中可能包括與SADS相關的病症。研究第二部份的 兩年前瞻性研究則對 21 名SCD猝死者進行分析：10\%有心律失常性右 心室心肌病、 $5 \%$ 有肥厚性心肌病, 其餘 $85 \%$ 在傳統解剖中無法找到 死因。基因分析顯示 $29 \%$ 有異合基因變異 ; 當中六種變異未曾有文獻 報導。此外, 三分一的猝死者有量厥史, $14 \%$ 有SCD家族史。11名接 受基因檢測的直系親屬中, 一半以上帶有相關基因變異, $10 \%$ 出現與 SADS相關的臨床徵狀。

結論：本項先導可行性研究確定了於東亞人中年輕SCD猝死者的死因 調查中結合直系親屬的臨床評估和次世代基因測序的價值，首次為本 港SADS提供重要基因數據及寶貴經驗, 屬本港基因研究的一項重大 發展, 且亦為法醫檢驗、次世代基因測序應用、遺傳諮詢、臨床評估 及轉介等流程奠定基礎。SCD的相關基因變異具複雜性, 我們建議由 合資格的病理科醫生進行分析及報告。

\section{Introduction}

Sudden death is defined as death occurring within 1 hour of the onset of symptoms or within 24 hours of the victim being seen alive. ${ }^{1}$ Sudden death due to an underlying heart disease is known as sudden cardiac death (SCD). The worldwide annual incidence of SCD is about 4 to 5 million cases per year. ${ }^{2} \mathrm{~A}$ tragic and devastating complication of a number of heart diseases, SCD is most often unexpected and has major implications for the surviving family and the community. The majority of SCD cases in middleaged and older individuals are caused by coronary artery disease; however, SCD is rare in young people and the causes are more diversified., ${ }^{3,4}$ Autopsy studies have shown no structural heart disease was found in up to $30 \%$ of young SCD victims. ${ }^{5-8}$

Molecular autopsy was first described by Ackerman et $\mathrm{al}^{9}$ in 1999, to determine the cause of death in uncertain cases after conventional autopsy by genetic analysis. Post-mortem genetic studies have shown that SCD in these victims can be caused by fatal arrhythmias secondary to a group of inheritable cardiac electrical disorders collectively known as sudden arrhythmia death syndrome (SADS). ${ }^{10-14}$ These include Brugada syndrome (BrS), long QT syndrome (LQTS), short QT syndrome, catecholaminergic polymorphic ventricular tachycardia (CPVT), arrhythmogenic right ventricular cardiomyopathy (ARVC), hypertrophic cardiomyopathy (HCM), and other cardiomyopathies.

Because SADS-related conditions are genetic diseases, there are two different approaches to identify SADS among young sudden unexplained death (SUD) victims. The first approach involves detailed clinical and targeted genetic examination of the surviving relatives of SCD victims. Studies using this approach suggest that SADS may account for approximately $40 \%$ of autopsy-negative sudden death in young people. ${ }^{10,15}$ However, this approach may not be able to identify subjects with concealed form of SADS due to incomplete penetrance and variable expressivity of the pathological mutations. The second approach is to perform molecular autopsy on SCD victims, which involves post-mortem genetic testing for SADS. A landmark study on molecular autopsy by the Mayo Clinic showed over one third of SCD cases hosted a presumably pathogenic mutations of cardiac ion channel diseases. ${ }^{8,16}$ Thus a combined approach using both cardiac evaluation of surviving relatives and molecular autopsy on SUD victims should give a higher yield on elucidating the underlying causes of SUD.

In Hong Kong, there are scarce data on the prevalence and types of SADS underlying SCD or SUD in young people. The present study aimed to investigate the prevalence and types of SADS in an East Asian population, and to perform a pilot study on incorporating cardiac evaluation of surviving relatives and molecular autopsy by next-generation sequencing (NGS) into conventional forensic investigations.

\section{Methods}

In the present study, first, we carried out a 5-year retrospective review of the records of all autopsies for young sudden death victims performed in public mortuaries in Hong Kong. Second, we conducted a 2-year study to determine the prevalence and types of SADS as the underlying causes of SCD among local young victims through conventional and molecular autopsy, and evaluated their first-degree relatives.

\section{Five-year retrospective review of autopsy records}

The Forensic Pathology Service, Department of Health, provides all public autopsy services for over 7 million people in Hong Kong. We performed this retrospective review of the records of all autopsies in public mortuaries for young sudden death victims (aged 5-40 years) between 1 January 2008 and 31 
December 2012. Sudden death was defined as death occurring within 1 hour of the onset of symptoms or within 24 hours of the victim being seen alive. ${ }^{1}$ Sudden death victims were recruited into the study for a detailed review of their autopsy records. Data including age, height, weight, sex, circumstances of death, clinical history of cardiac disease, and pathologic findings at autopsy were collected and analysed. Sudden death victims whose deaths were caused by trauma, accidents, drowning, and drug toxicity, and those whose autopsy records were either incomplete or not accessible for retrospective review were excluded.

\section{Two-year prospective study by conventional and molecular autopsy}

In this prospective study, young SCD victims (aged 5-40 years) were identified and recruited into the study by forensic pathologists after a finding of either an inheritable arrhythmogenic cardiomyopathy or no anatomical cause of death (including other structural heart disease) on autopsy, and a negative toxicology screening. Clinical history, including personal history of arrhythmic events and history surrounding the sudden death event of the SCD victim was collected during identification interviews with next-of-kin as far as possible by forensic pathologists. DNAfriendly blood samples were collected for molecular autopsy. Written informed consent for a molecular autopsy was obtained from the next-of-kin of each victim. The first-degree relatives of the victims were referred by forensic pathologists to the study centre for genetic counselling and recruitment into the study. Clinical history, including personal history of arrhythmic events and history surrounding the sudden death event of the SCD victim was collected from family members. All recruited first-degree relatives underwent clinical evaluation including 12-lead electrocardiogram (ECG), signal-averaged ECG, echocardiogram, 24-hour Holter analysis and treadmill exercise testing. Additional investigations were used only as required, such as flecainide provocation testing (if $\mathrm{BrS}$ is suspected in subjects $>18$ years) and targeted genetic screening (if positive molecular autopsy findings in the index SUD victim). All first-degree relatives provided written informed consent for these procedures and for publication of the results.

A panel of 35 genes implicated in SADS for BrS, LQTS, short QT syndrome, CPVT, ARVC, and HCM was tested using NGS (Table 1). The NGS was performed using targeted gene capture technique on a MiSeq Sequencing System (Illumina, Inc, San Diego [CA], United States). Target regions of interest were restricted to the coding regions and the 10-bp flanking regions. Target rates indicated percentage of bases with a minimum depth of coverage of 20x. Alignments to the February 2009 (GRCh37/
TABLE I. All 35 genes included in the SADS gene panel analysed by next-generation sequencing

\begin{tabular}{lccccc}
\hline Gene & LQTS & BrS & CPVT & ARVC & HCM \\
\hline AKAP9 & + & & & & \\
ANK2 & + & & & & \\
CACNA1C & + & + & & & \\
CACNB2 & & + & & & + \\
CASQ2 & & & + & & \\
CAV3 & + & & & & + \\
DSC2 & & & & + & + \\
$D S G 2$ & & & & + & + \\
$D S P$ & & & & +
\end{tabular}

GPD1L $\quad+$

$\begin{array}{lll}\text { HCN4 } & + & \\ \text { JUP } & +\end{array}$

KCND3 +

KCNE1 +

KCNE2 +

KCNE3 +

$\begin{array}{lll}K C N H 2 & + & \\ \text { KCNJ2 } & + & \\ \text { KCNJ8 } & & +\end{array}$

$\begin{array}{llll} & + & & \\ \text { KCNQ1 } & + & & \\ \text { LMNA } & & +\end{array}$

MYBPC3 +

MYH7 + +

PKP2 +

$\begin{array}{llll}\text { RANGRF } & + & & \\ \text { RYR2 } & & + & +\end{array}$

\begin{tabular}{|c|c|c|c|c|}
\hline SCN1B & & + & & \\
\hline SCN3B & & + & & \\
\hline SCN4B & + & & & \\
\hline SCN5A & + & + & & \\
\hline SNTA1 & + & & & \\
\hline TGFB3 & & & + & \\
\hline TMEM43 & & & + & \\
\hline TNNI3 & & & & + \\
\hline TNNT2 & & & & + \\
\hline
\end{tabular}

Abbreviations: ARVC = arrhythmogenic right ventricular cardiomyopathy; $\mathrm{BrS}=$ Brugada syndrome; CPVT =

catecholaminergic polymorphic ventricular tachycardia; HCM = hypertrophic cardiomyopathy; LQTS = long QT syndrome; SADS = sudden arrhythmia death syndrome

hg19) human genome assembly and variant calls were generated using dual pipelines, SoftGenetics NextGENe (v2.4.1) and an in-house one where sequencing reads were aligned by Burrows-Wheeler Aligner (v0.7.5a-r405) to hg19 genome and processed with picard-tools (v1.114). Local realignment for indels and base quality recalibration were performed 
with Genome Analysis Toolkit (GATK, v3.2). Variant calls were made with UnifiedGenotyper (GATK v3.2). Only those genes included in the requested gene panel were processed for variant calling. Variants identified were annotated and analysed with VariantStudio (v2.2.1; Illumina, Inc); in general, variants with an allele frequency of $<0.1 \%$ for dominant disorders or $<1.0 \%$ for recessive disorders were reported. Pathogenic and likely pathogenic variants were confirmed by Sanger sequencing; benign and likely benign variants were not reported. The genetic variant pathogenicity was established according to the Practice Guidelines for the Interpretation and Reporting of Unclassified Variants in Clinical Molecular Genetics by the Clinical Molecular Genetics Society (http:// www.acgs.uk.com/media/774853/evaluation and_reporting_of_sequence_variants_bpgs_ june_2013_-_finalpdf.pdf). Major criteria include degree of conservation, population allele frequencies, co-segregation pattern, literature data, functional studies and in silico prediction. The pathogenicity of novel missense variants was analysed by PolyPhen-2, SIFT, MutationTaster and Assessing Pathogenicity Probability in Arrhythmia by Integrating Statistical Evidence (https://cardiodb.org/APPRAISE/) and that of novel splicing variants was by Splice Site Finder-like, MaxEntScan, GeneSplicer and Human Splicing Finder, wherever appropriate. Splicing variants were considered to be damaging if the score was more than $10 \%$ lower than the wild-type prediction. Allele frequencies among populations were as reported in the Genome Aggregation Database (gnomAD, http://gnomad.broadinstitute. $\operatorname{org} /)$.

A diagnosis of SADS was established when molecular autopsy in SCD victims identified a positive genetic variant implicated in SADS or generally accepted clinical criteria for a particular disease were fulfilled in the SCD victims or their first-degree relatives. The descriptive statistics were analysed using Excel 2016 (Microsoft Corp, Redmond [WA], United States).

\section{Results}

\section{Five-year retrospective review of autopsy records}

There were 17187 autopsies performed during the study period and 2748 (16\%) deaths were aged 5 to 40 years. There were 420 sudden death victims. Among them, 289 (69\%) were SCD (male:female ratio=9:2). The median age was 32 years (range, $7-40$ years). Coronary artery diseases accounted for $35 \%$ of the causes of death; other causes of death were aortic dissection (6\%), myocarditis (6\%), left ventricular hypertrophy (4\%), dilated cardiomyopathy (9\%), other structural heart diseases (9\%), HCM (4\%), ARVC (2\%), and unexplained (25\%).

\section{Two-year study by conventional and molecular autopsy}

There were 32 SCD victims aged 5 to 40 years between 1 July 2014 and 30 June 2016 with a finding of either an inheritable arrhythmogenic cardiomyopathy or no anatomical cause of death (including other structural heart disease) on autopsy and negative toxicology results. Eleven individuals were excluded: two who had no Hong Kong identity card and nine whose families refused consent. Finally, 21 SCD victims (18 male, 3 female) were recruited into the study. Table 2 shows the clinical and forensic data of the 21 SCD victims. The median age was 31 years (range, 14-39 years). From the conventional autopsy, 18 (86\%) were unrevealing; two (10\%) SCD victims had ARVC and one $(5 \%)$ had HCM. The majority died during resting $(48 \%)$ or sleeping $(24 \%)$. Only three SCD victims (14\%) died during exercise. Three (14\%) SCD victims had family history of SCD and seven (33\%) had a history of syncope. Many (71\%) of the SCD victims had unremarkable past health. Genetic analysis showed 29\% with positive heterozygous genetic variants (Table 3 ). Seven variants were identified in seven genes, six variants of which were novel. The genetic background was heterogeneous without any common mutations found. Combining conventional and molecular autopsy findings, the cause of death in 12 (57\%) still remains unknown; cause of death was confirmed in four (19\%) as ARVC, in two (10\%) as $\mathrm{BrS}$, and one (5\%) each in HCM, LQTS, and CPVT.

Overall, more than half of first-degree relatives (6 of 11 individuals) who underwent genetic testing carried the positive genetic variants. Among them, SADS-related clinical features were detected in three first-degree relatives from two families (cases 14 and 16). The true clinical phenotype can sometimes be detected in surviving relatives upon appropriate clinical evaluation, which in turn significantly aids the interpretation of genetic findings. Cases 14 and 16 illustrate the importance of this (Fig 1). The firstdegree relatives of these two cases showed SADSrelated clinical features after cardiologist's assessment.

Case 14 was a 17-year-old male victim who died of sudden nocturnal death. He had an episode of syncope few months prior to his death but he did not seek medical attention. Family screening by clinical evaluation found no structural heart disease but ECG revealed prolonged QTc interval in his asymptomatic father and sister (530 ms and $480 \mathrm{~ms}$, respectively) suggesting a diagnosis of LQTS (Fig 1). Molecular autopsy found heterozygous NM_199460.2(CACNA1C):c.2276C >G NP_955630.2:p.(Ala759Gly). This novel variant is predicted to be damaging and absent in the gnomAD. $C A C N A 1 C$ is the gene encoding for the alpha-1c subunit of the type 1 voltage-dependent calcium channel involved in the cardiac myocyte membrane polarisation. Its mutations have been reported in $\mathrm{BrS}$ and LQTS. 
TABLE 2. Clinical and forensic data of the 2I SCD victims

\begin{tabular}{|c|c|c|c|c|c|}
\hline Case & $\begin{array}{l}\text { Sex/ } \\
\text { age } \\
\text { (years) }\end{array}$ & Clinical details & Family history of SCD & $\begin{array}{l}\text { Forensic findings } \\
\text { (autopsy and } \\
\text { toxicology screening) }\end{array}$ & Molecular autopsy findings \\
\hline 1 & $M / 26$ & $\begin{array}{l}\text { Known autism and mental retardation. On } \\
\text { antipsychotic and anti-epileptic drugs. Found } \\
\text { unconscious on bed in hostel }\end{array}$ & No & Negative & Negative \\
\hline 2 & $M / 22$ & Good past health. Found collapsed at home & $\begin{array}{l}\text { Yes (mother and } \\
\text { maternal aunt had SCD } \\
\text { at 20s-30s) }\end{array}$ & Negative & Negative \\
\hline 3 & $\mathrm{M} / 38$ & $\begin{array}{l}\text { Chronic smoker. Good past health. Found } \\
\text { unconscious on bed at home }\end{array}$ & No & Negative & Negative \\
\hline 4 & $\mathrm{M} / 27$ & $\begin{array}{l}\text { History of substance abuse. Found unconscious } \\
\text { on bed at detoxification centre }\end{array}$ & No & Negative & Negative \\
\hline 5 & $\mathrm{M} / 32$ & $\begin{array}{l}\text { Known mental retardation and epilepsy. Found } \\
\text { collapsed in hostel }\end{array}$ & No & $\begin{array}{l}\text { Autopsy as ARVC and } \\
\text { toxicology negative }\end{array}$ & $\begin{array}{l}\text { NM_024422.3(DSC2):c.2368G>A } \\
\text { (p.Gly790Arg) }{ }^{*}\end{array}$ \\
\hline 6 & $\mathrm{M} / 33$ & $\begin{array}{l}\text { Good past health. Played football the night } \\
\text { before and felt chest discomfort. Found } \\
\text { unconscious on bed in the next morning }\end{array}$ & No & Negative & Negative \\
\hline 7 & $F / 14$ & $\begin{array}{l}\text { Birth asphyxia with no residual effects. Dizziness } \\
\text { with sweating and paleness in past } 2 \text { to } 3 \\
\text { months. Suddenly collapsed in school after } \\
\text { lunch. Given defibrillation on ambulance }\end{array}$ & No & Negative & NM_005751.4(AKAP9):c.3752-1G>A* \\
\hline 8 & $F / 14$ & $\begin{array}{l}\text { History of ovarian cyst and menorrhagia. } \\
\text { Suddenly collapsed at home. Electrocardiogram } \\
\text { showed ventricular fibrillation with defibrillation } \\
\text { on ambulance and at the Emergency Department }\end{array}$ & No & Negative & Negative \\
\hline 9 & $F / 26$ & $\begin{array}{l}\text { Good past health. Found collapsed in swimming } \\
\text { pool }\end{array}$ & $\begin{array}{l}\text { Yes (elder brother had } \\
\text { history of recurrent } \\
\text { syncope and sudden } \\
\text { death at } 17 \text { years) }\end{array}$ & $\begin{array}{l}\text { Autopsy as ARVC and } \\
\text { toxicology negative }\end{array}$ & Negative \\
\hline 10 & $\mathrm{M} / 32$ & $\begin{array}{l}\text { History of exertional syncope. Found } \\
\text { unconscious on bed at home }\end{array}$ & $\begin{array}{l}\text { Yes (paternal cousin } \\
\text { had sudden death at } \\
24 \text { years) }\end{array}$ & Negative & $\begin{array}{l}\text { NM_001035.2(RYR2):c.1509C>A } \\
(\text { (p.Asp503Glu)* }\end{array}$ \\
\hline 11 & $\mathrm{M} / 36$ & $\begin{array}{l}\text { Good past health. Recent fever and diarrhoea. } \\
\text { Found unconscious on bed at home }\end{array}$ & No & Negative & Negative \\
\hline 12 & $\mathrm{M} / 32$ & $\begin{array}{l}\text { Good past health. Low-grade fever for } 1 \text { day. } \\
\text { Enterovirus positive. Found unconscious on bed } \\
\text { at home. Electrocardiogram showed ventricular } \\
\text { fibrillation with defibrillation at the Emergency } \\
\text { Department }\end{array}$ & No & Negative & Negative \\
\hline 13 & $\mathrm{M} / 27$ & $\begin{array}{l}\text { Good past health. Lived in Shenzhen. Found } \\
\text { unconscious on bed at home. Body transferred } \\
\text { to Hong Kong }\end{array}$ & No & $\begin{array}{l}\text { Autopsy as } \mathrm{HCM} \text { and } \\
\text { toxicology negative }\end{array}$ & Negative \\
\hline 14 & $\mathrm{M} / 17$ & $\begin{array}{l}\text { History of chest discomfort and fainting during } \\
\text { bathing few months ago. Found unconscious on } \\
\text { bed at home }\end{array}$ & No & Negative & $\begin{array}{l}\text { NM_199460.2(CACNA1C):c.2276C>G } \\
\text { (p.Ala759Gly) })^{*}\end{array}$ \\
\hline 15 & $\mathrm{M} / 27$ & $\begin{array}{l}\text { Good past health. Found unconscious on bed } \\
\text { at home }\end{array}$ & No & Negative & Negative \\
\hline 16 & $\mathrm{M} / 19$ & $\begin{array}{l}\text { Good past health. Found unconscious on bed } \\
\text { at home }\end{array}$ & No & $\begin{array}{l}\text { Autopsy as suspected } \\
\text { pulmonary arterial } \\
\text { hypertension and } \\
\text { toxicology negative }\end{array}$ & $\begin{array}{l}\text { NM_198056.2(SCN5A):c.2893C>T } \\
\text { (p.Arg965Cys) }\end{array}$ \\
\hline 17 & $\mathrm{M} / 31$ & $\begin{array}{l}\text { History of pulmonary tuberculosis and hepatitis. } \\
\text { Found collapsed at workplace }\end{array}$ & No & Negative & Negative \\
\hline 18 & M/33 & $\begin{array}{l}\text { Chronic smoker. Good past health. Found } \\
\text { collapsed at home. Electrocardiogram showed } \\
\text { ventricular fibrillation with defibrillation at the } \\
\text { Emergency Department }\end{array}$ & No & Negative & Negative \\
\hline 19 & $\mathrm{M} / 35$ & $\begin{array}{l}\text { Chronic drinker. Good past health. Found } \\
\text { collapsed at home }\end{array}$ & No & Negative & Negative \\
\hline 20 & M/39 & $\begin{array}{l}\text { Good past health. Suddenly collapsed during } \\
\text { ball game. Electrocardiogram showed ventricular } \\
\text { fibrillation with defibrillation at the Emergency } \\
\text { Department }\end{array}$ & No & $\begin{array}{l}\text { Autopsy as } \mathrm{HCM} \text { and } \\
\text { toxicology negative }\end{array}$ & $\begin{array}{l}\text { NM_004415.3(DSP):c.1045G >C } \\
\text { (p.Ala349Pro)* } \\
\text { NM_002230.2(JUP):c.751C>A } \\
\text { (p.His251Asn) }\end{array}$ \\
\hline 21 & $M / 38$ & $\begin{array}{l}\text { Good past health. Found unconscious on bed } \\
\text { at home }\end{array}$ & No & $\begin{array}{l}\text { Autopsy as ARVC and } \\
\text { toxicology negative }\end{array}$ & Negative \\
\hline
\end{tabular}

Abbreviations: ARVC = arrhythmogenic right ventricular cardiomyopathy; HCM = hypertrophic cardiomyopathy; SCD = sudden cardiac death

* Novel variant 
TABLE 3. Positive genetic findings of six sudden cardiac death cases detected by next-generation sequencing

\begin{tabular}{|c|c|c|c|c|}
\hline \multirow[t]{2}{*}{ Case } & \multirow[t]{2}{*}{ Genetic findings } & \multirow{2}{*}{$\begin{array}{l}\text { Allele frequency by } \\
\text { gnomAD }\end{array}$} & \multirow{2}{*}{$\begin{array}{l}\text { In silico prediction } \\
\text { a. PolyPhen-2 } \\
\text { b. MetaSVM } \\
\text { c. PROVEAN }\end{array}$} & \multirow[t]{2}{*}{ HGMD accession } \\
\hline & & & & \\
\hline 5 & NM_024422.3(DSC2):c.2368G>A (p.Gly790Arg)* & $\begin{array}{l}0.0004 \%(1 / 245 \text { 860, all }) \\
0.0058 \%(1 / 17240, \text { EAS })\end{array}$ & $\begin{array}{l}\text { a. Probably damaging } \\
\text { b. Damaging } \\
\text { c. Damaging }\end{array}$ & - \\
\hline 7 & NM_005751.4(AKAP9):c.3752-1G>A* & - & $\begin{array}{l}\text { Abolishment of acceptor } \\
\text { splice site (Splice Site Finder, } \\
\text { MaxEntScan, GeneSplicer, } \\
\text { Human Splicing Finder) }\end{array}$ & - \\
\hline 10 & NM_001035.2(RYR2):c.1509C>A (p.Asp503Glu)* & $\begin{array}{l}0.0008 \%(2 / 242560, \text { all }) \\
0 \%(0 / 1620, \text { EAS) }\end{array}$ & $\begin{array}{l}\text { a. Probably damaging } \\
\text { b. Damaging } \\
\text { c. Damaging }\end{array}$ & - \\
\hline 14 & NM_199460.2(CACNA1C):c.2276C>G (p.Ala759Gly) ${ }^{\star}$ & - & $\begin{array}{l}\text { a. Probably damaging } \\
\text { b. Damaging } \\
\text { c. Damaging }\end{array}$ & - \\
\hline 16 & NM_198056.2(SCN5A):c.2893C>T (p.Arg965Cys) & $\begin{array}{l}0.0066 \%(16 / 243648, \text { all }) \\
0.058 \%(10 / 17136, \text { EAS) }\end{array}$ & $\begin{array}{l}\text { a. Probably damaging } \\
\text { b. Damaging } \\
\text { c. Damaging }\end{array}$ & $\begin{array}{l}\text { CM024644 (Brugada } \\
\text { syndrome) }\end{array}$ \\
\hline 20 & $\begin{array}{l}\text { NM_004415.3(DSP):c.1045G>C (p.Ala349Pro)* } \\
\text { NM_002230.2(JUP):c.751C>A (p.His251Asn) }{ }^{\star}\end{array}$ & - & $\begin{array}{l}\text { a. Probably damaging } \\
\text { b. Damaging } \\
\text { c. Damaging } \\
\text { a. Probably damaging } \\
\text { b. Damaging } \\
\text { c. Damaging }\end{array}$ & - \\
\hline
\end{tabular}

Abbreviations: all = allele frequency in all populations; EAS = allele frequency in East Asian populations; gnomAD = Genome Aggregation Database; HGMD: Human Gene Mutation Database Professional 2017.2

* Novel variant

Case 16 was a 19-year-old male victim who also died of sudden nocturnal death. There was no known syncope or preceding symptoms ahead of the collapse. He had history of abnormal heart beat, although ECG was not done. His family history was unremarkable. Autopsy revealed pulmonary hypertension. Molecular autopsy detected heterozygous NM_198056.2(SCN5A):c.2893C > T (p.Arg965Cys) which has been reported as a disease causing mutation of BrS. ${ }^{17-19}$ The same variant has also been reported in patients with LQTS (with digenic mutation in $\mathrm{KCNH} 2$ in one case). ${ }^{20,21}$ The allele frequency of this variant (rs199473180) is reported to be $0.058 \%$ in East Asians (gnomAD). In silico analyses by SIFT, MutationTaster, and PolyPhen-2 have revealed this variant to be damaging, disease causing, and probably damaging, respectively. Functional study showed that the p.(Arg965Cys) mutant led to slower recovery from inactivation as a result of channels with a more negative potential in steady state inactivation. ${ }^{18}$ Family screening found his father carrying the same SCN5A mutation and a type 2 Brugada ECG pattern (Fig 1). However, no type 1 Brugada ECG feature was revealed by a flecainide provocation test. The clinical phenotype in this case supports the pathogenicity of this novel genetic variant.

\section{Discussion}

To elucidate the cause of SCD, a comprehensive post-mortem evaluation is required. Figure 2 shows the combined approach using both cardiac evaluation of surviving relatives and molecular autopsy on SUD victims which would give a higher yield on elucidating the underlying causes of SUD. Any history of syncope, cardiac symptoms especially related to exertion, emotion and stress, previous ECG, circumstances of SCD (activity at the time of death), any family history of cardiac disease, premature or sudden death, near-arrest attack, and epilepsy should be investigated. Patients with SADS can present with or be (incorrectly) labelled as having epilepsy. ${ }^{22-25}$ Guidelines on post-mortem examination of SUD in the young have been published by the Royal College of Pathologists of Australasia (https://www.rcpa. edu.au/getattachment/89884c69-f066-411d-a3d139460444db13/Guidelines-on-Autopsy-Practice. aspx). In addition to traditional autopsy, some reports have used whole-body computed tomography and magnetic resonance imaging to identify structural heart abnormalities such as ARVC and HCM. ${ }^{26,27}$ However, these imaging modalities were not used in the present study.

Technologies applied in molecular autopsy have changed from Sanger sequencing targeting a 
few major SUD-related genes to NGS targeting an expanded gene panel of up to 200 genes. ${ }^{28}$ The former approach achieved diagnostic yields of around $15 \%$ to 20\%. ${ }^{8,16,29-32}$ With increasing throughput capacities at more affordable costs, the large gene panel or exome approach by NGS is becoming more appealing in molecular autopsy. A proof-of-principle exomewide study was carried out among 50 SUD subjects, with likely pathogenic variants identified in $32 \%{ }^{33}$ The diagnostic yield from various NGS studies, including our own, is up to $35 \%$, despite the different lengths of gene lists. ${ }^{13,34-36}$ However, the spectrum of diseases might be different and rarer causes might be identified, because substantial clinical suspicion is typically lacking among young SCD victims with unremarkable premorbid history. However, a negative genetic result does not necessarily exclude the possibility of a genetic basis for the disease.

The major difficulty of molecular autopsy is establishing the causation between the death and the genetic variants. Applying molecular autopsy to the investigation of death causes involves probabilistic rather than binary "yes or no" answers. Interpretation of variant pathogenicity relies heavily on the characteristics of the genetic variant, allele rarity in population frequencies, in silico predictions, co-segregation patterns among affected family members, previous literature data on reports of similar cases, and available functional data. This approach follows the usual practice by which pathologists deal with genetic reporting.

There are two main advantages of molecular autopsy in SCD. First, molecular autopsy enables a correct diagnosis of SCD to be established, which can bring some level of closure to the family. Findings of a SADS-related condition can differentiate a natural cause from an unnatural cause of death, such as the possibility of drowning precipitated by an inherited arrhythmia during swimming. Second, the ultimate goal of diagnosing SCD is to prevent another tragedy among family members. The majority of SADSrelated disorders are autosomal dominant inherited, and family members are at $50 \%$ risk of inheriting the mutation, with variable penetrance. Family pedigree for at least three generations should be included in the extended clinical workup, and genetic counselling should be considered for second- or higher-degree relatives wherever appropriate.

There are limitations to our study. First, SCD victims with autopsy conducted in a public hospital were not recruited in this study. Hence, the sample numbers may not be representative for the whole territory. Second, no premorbid ECG findings of the victims were available to correlate with the genetic results. Third, despite multiple efforts, no genetic mutations were found in over two thirds of the SCD victims in our study. Expanding the gene list may be able to increase the yield. The associated phenotypes

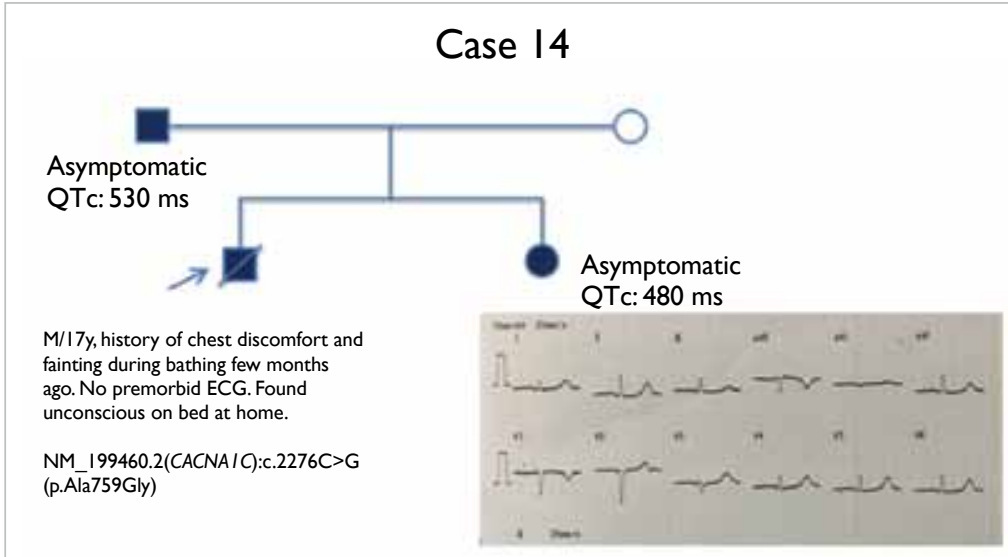

Case 16

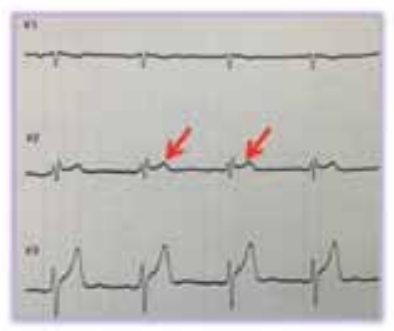

Asymptomatic Brugada type I

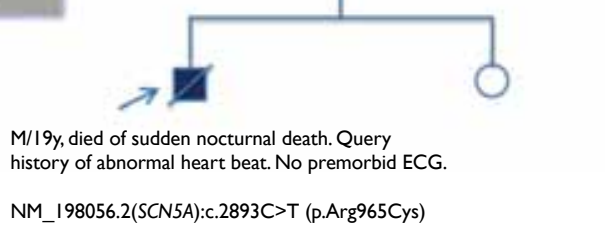

FIG I. Pedigrees of cases 14 and 16 with SADS-related clinical features Abbreviations: ECG = electrocardiogram; SADS = sudden arrhythmia death syndrome

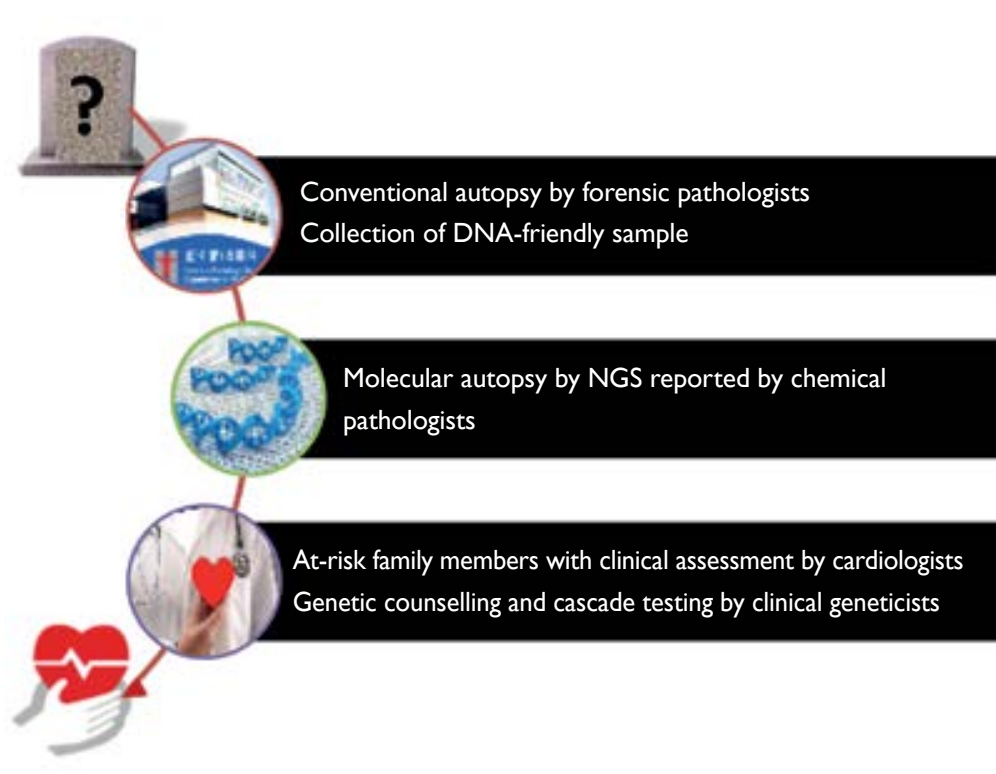

FIG 2. Proposed model of combining molecular autopsy and clinical assessment with conventional forensic investigation

Abbreviation: NGS = next-generation sequencing 
and pathogenesis of some genes are still yet to be further elucidated.

\section{Conclusion}

Sudden arrhythmia death syndrome is a significant cause of SCD in the young. This study is first of its kind in an East Asian population and provides important data on the prevalence and types of SADS among young SCD victims. This is also the first local feasibility study on incorporating cardiac evaluation of surviving relatives and NGS molecular autopsy into the conventional forensic investigations. The interpretation of genetic variants in the context of SCD is complicated and we recommend its analysis and reporting by qualified pathologists. This model may be considered to cover all age-groups of SCD victims, as well as other potential applications such as sudden unexpected death in epilepsy, or sudden infant death syndrome. This local pilot study should be considered an important advance in diagnosing young SCD victims in East Asian populations.

\section{Author contributions}

All authors have made substantial contributions to the concept or design of the study, acquisition of data, analysis or interpretation of data, drafting of the manuscript, and critical revision for important intellectual content. All authors had full access to the data, contributed to the study, approved the final version for publication, and take responsibility for its accuracy and integrity.

\section{Conflicts of interest}

All authors have disclosed no conflicts of interest.

\section{Declaration}

The 5-year review was presented at the Asia Pacific Heart Rhythm Society Meeting on 3 to 6 October 2013, in Hong Kong. Part of the SADS HK Study results was presented at CardioRhythm on 24 to 26 February 2017, in Hong Kong and was published (J HK Coll Cardiol 2016;24:34).

\section{Funding/support}

This work was partly funded by SADS HK Foundation Limited, Hong Kong.

\section{Ethics approval}

The study was approved by local ethics committees (Ethic Committee of the Department of Health (L/M 601/2013) and Kowloon West Cluster Research Ethics Committee (KWC-REC Reference KW/FR-13-023-67-05)). Consent was obtained from the next-of-kin of the SCD victims and from the first-degree relatives themselves under study.

\section{References}

1. Puranik R, Chow CK, Duflou JA, Kilborn MJ, McGuire MA. Sudden death in the young. Heart Rhythm 2005;2:1277-82.

2. Chugh SS, Reinier K, Teodorescu C, et al. Epidemiology of sudden cardiac death: clinical and research implications.
Prog Cardiovasc Dis 2008;51:213-28.

3. Basso C, Corrado D, Thiene G. Cardiovascular causes of sudden death in young individuals including athletes. Cardiol Rev 1999;7:127-35.

4. Link MS. Sudden cardiac death in the young: epidemiology and overview. Congenit Heart Dis 2017;12:597-9.

5. Chugh SS, Kelly KL, Titus JL. Sudden cardiac death with apparently normal heart. Circulation 2000;102:649-54.

6. Corrado D, Basso C, Thiene G. Sudden cardiac death in young people with apparently normal heart. Cardiovasc Res 2001;50:399-408.

7. de Noronha SV, Sharma S, Papadakis M, Desai S, Whyte G, Sheppard MN. Aetiology of sudden cardiac death in athletes in the United Kingdom: a pathological study. Heart 2009;95:1409-14.

8. Tester DJ, Medeiros-Domingo A, Will ML, Haglund CM, Ackerman MJ. Cardiac channel molecular autopsy: insights from 173 consecutive cases of autopsy-negative sudden unexplained death referred for postmortem genetic testing. Mayo Clin Proc 2012;87:524-39.

9. Ackerman MJ, Tester DJ, Driscoll DJ. Molecular autopsy of sudden unexplained death in the young. Am J Forensic Med Pathol 2001;22:105-11.

10. Tester DJ, Ackerman MJ. The role of molecular autopsy in unexplained sudden cardiac death. Curr Opin Cardiol 2006;21:166-72.

11. Wever-Pinzon OE, Myerson M, Sherrid MV. Sudden cardiac death in young competitive athletes due to genetic cardiac abnormalities. Anadolu Kardiyol Derg 2009;9 Suppl 2:17-23.

12. Hellenthal N, Gaertner-Rommel A, Klauke B, et al. Molecular autopsy of sudden unexplained deaths reveals genetic predispositions for cardiac diseases among young forensic cases. Europace 2017;19:1881-90.

13. Hertz CL, Christiansen SL, Ferrero-Miliani L, et al. Nextgeneration sequencing of 100 candidate genes in young victims of suspected sudden cardiac death with structural abnormalities of the heart. Int J Legal Med 2016;130:91-102.

14. Christiansen SL, Hertz CL, Ferrero-Miliani L, et al. Genetic investigation of 100 heart genes in sudden unexplained death victims in a forensic setting. Eur J Hum Genet 2016;24:1797-802.

15. Semsarian C, Hamilton RM. Key role of the molecular autopsy in sudden unexpected death. Heart Rhythm 2012;9:145-50.

16. Tester DJ, Spoon DB, Valdivia HH, Makielski JC, Ackerman MJ. Targeted mutational analysis of the RyR2-encoded cardiac ryanodine receptor in sudden unexplained death: a molecular autopsy of 49 medical examiner/coroner's cases. Mayo Clin Proc 2004;79:1380-4.

17. Priori SG, Napolitano C, Gasparini M, et al. Natural history of Brugada syndrome: insights for risk stratification and management. Circulation 2002;105:1342-7.

18. Hsueh $\mathrm{CH}$, Chen WP, Lin JL, et al. Distinct functional defect of three novel Brugada syndrome related cardiac sodium channel mutations. J Biomed Sci 2009;16:23.

19. $\mathrm{Yu} \mathrm{JH}, \mathrm{Hu} \mathrm{JZ}$, Zhou H, et al. SCN5A mutation in patients with Brugada electrocardiographic pattern induced by fever [in Chinese]. Zhonghua Xin Xue Guan Bing Za Zhi 2013;41:1010-4.

20. Jimmy JJ, Chen CY, Yeh HM, et al. Clinical characteristics of patients with congenital long QT syndrome and bigenic mutations. Chin Med J (Engl) 2014;127:1482-6. 
21. Lieve KV, Williams L, Daly A, et al. Results of genetic testing in 855 consecutive unrelated patients referred for long QT syndrome in a clinical laboratory. Genet Test Mol Biomarkers 2013;17:553-61.

22. Medford BA, Bos JM, Ackerman MJ. Epilepsy misdiagnosed as long QT syndrome: it can go both ways. Congenit Heart Dis 2014;9:E135-9.

23. Partemi S, Cestèle S, Pezzella M, et al. Loss-of-function $\mathrm{KCNH} 2$ mutation in a family with long QT syndrome, epilepsy, and sudden death. Epilepsia 2013;54:e112-6.

24. Goyal JP, Sethi A, Shah VB. Jervell and Lange-Nielson Syndrome masquerading as intractable epilepsy. Ann Indian Acad Neurol 2012;15:145-7.

25. Tu E, Bagnall RD, Duflou J, Semsarian C. Post-mortem review and genetic analysis of sudden unexpected death in epilepsy (SUDEP) cases. Brain Pathol 2011;21:201-8.

26. Roberts IS, Benamore RE, Benbow EW, et al. Post-mortem imaging as an alternative to autopsy in the diagnosis of adult deaths: a validation study. Lancet 2012;379:136-42.

27. Puranik R, Gray B, Lackey $H$, et al. Comparison of conventional autopsy and magnetic resonance imaging in determining the cause of sudden death in the young. J Cardiovasc Magn Reson 2014;16:44.

28. Semsarian C, Ingles J. Molecular autopsy in victims of inherited arrhythmias. J Arrhythm 2016;32:359-65.

29. Liu C, Zhao Q, Su T, et al. Postmortem molecular analysis of KCNQ1, KCNH2, KCNE1 and KCNE2 genes in sudden unexplained nocturnal death syndrome in the Chinese Han population. Forensic Sci Int 2013;231:82-7.

30. Doolan A, Langlois N, Chiu C, Ingles J, Lind JM, Semsarian C. Postmortem molecular analysis of KCNQ1 and SCN5A genes in sudden unexplained death in young Australians. Int J Cardiol 2008;127:138-41.

31. Skinner JR, Crawford J, Smith W, et al. Prospective, population-based long QT molecular autopsy study of postmortem negative sudden death in 1 to 40 year olds. Heart Rhythm 2011;8:412-9.

32. Hofman N, Tan HL, Alders M, et al. Yield of molecular and clinical testing for arrhythmia syndromes: report of 15 years' experience. Circulation 2013;128:1513-21.

33. Bagnall RD, Das KJ, Duflou J, Semsarian C. Exome analysisbased molecular autopsy in cases of sudden unexplained death in the young. Heart Rhythm 2014;11:655-62.

34. Bagnall RD, Weintraub RG, Ingles J, et al. A prospective study of sudden cardiac death among children and young adults. N Engl J Med 2016;374:2441-52.

35. Farrugia A, Keyser C, Hollard C, Raul JS, Muller J, Ludes B. Targeted next generation sequencing application in cardiac channelopathies: analysis of a cohort of autopsy-negative sudden unexplained deaths. Forensic Sci Int 2015;254:511.

36. Tester DJ, Ackerman MJ. Postmortem long QT syndrome genetic testing for sudden unexplained death in the young. J Am Coll Cardiol 2007;49:240-6. 